\title{
New Fungicides and Application Strategies Based on Inoculum and Precipitation for Managing Stone Fruit Rust on Peach in California
}

\author{
A. Soto-Estrada, H. Förster, Dept. of Plant Pathology, Univ. of California, Riverside, J. Hasey, University of \\ California, Coop. Ext., Yuba City, CA 95991, and J. E. Adaskaveg, Dept. of Plant Pathology, University of Califor- \\ nia, Riverside, CA 92521
}

\begin{abstract}
Soto-Estrada, A., Förster, H., Hasey, J., and Adaskaveg, J. E. 2003. New fungicides and application strategies based on inoculum and precipitation for managing stone fruit rust on peach in California. Plant Dis. 87:1094-1101.

In greenhouse and field studies, rust on cling peach caused by Tranzschelia discolor was significantly reduced on leaves and fruit compared with that on controls by foliar applications of wettable sulfur, an agricultural oil, a substituted aromatic (e.g., chlorothalonil), as well as benzimidazole (e.g., benomyl, thiophanate-methyl), sterol biosynthesis inhibiting (e.g., myclobutanil, propiconazole, tebuconazole), and strobilurin (e.g., azoxystrobin) fungicides. The timing of treatments was a significant factor in reducing disease in most trials. Protective programs using wettable sulfur, tebuconazole, or azoxystrobin applied after stem lesion detection (ASLD) and before forecasted rains were highly effective. In the most effective programs for managing the disease, however, these fungicides were applied after stem lesion detection and occurrence of rainfall. Under highly conducive field environments for disease, single applications of azoxystrobin or tebuconazole at ASLD were significantly more efficacious than sulfur. Dormant treatments of liquid lime sulfur, chlorothalonil, or thiophanate-methyl/agricultural oil, however, were ineffective in reducing the disease during the subsequent spring and summer seasons. This is the first management program for rust on cling peach that utilizes inoculum and precipitation events to optimize timing of fungicide applications.
\end{abstract}

Additional keywords: disease forecast, disease model

Stone fruit rust, caused by the biotrophic fungus Tranzschelia discolor (Fuckel) Tranzschel \& Litv., is widely distributed in California. The disease affects Prunus spp. such as peach, nectarine, plum, prune, almond, and cherry (15). Under favorable environmental conditions, the disease develops on leaves, fruit, and stems $(9,15)$. Symptoms on leaves include distinct angular, chlorotic lesions. On the lower leaf surface, light brown pustules form in the center of the lesions, where uredinia of the fungus produce single-celled urediniospores (1). These spores are formed in spring, summer, and early fall. In late fall, the uredinia become telia, which produce two-celled, darkly pigmented, pedicellate teliospores. Uredinia may also be found on fruit during the growing season and on stems in the spring. Early-season fruit infections result in sunken lesions as fruit mature. As the fruit ripen, rust lesions commonly have chlorotic halos and reddish-brown centers in which uredinia are produced.

Corresponding author: J. E. Adaskaveg

E-mail: jim.adaskaveg@ucr.edu

Accepted for publication 6 April 2003.

Publication no. D-2003-0616-05R

(C) 2003 The American Phytopathological Society
Infections on juvenile stems start as water-soaked lesions that develop into longitudinal splits in the epidermal tissue as uredinia are produced $(1,24)$. Pierce $(18)$ and Goldsworthy and Smith (9) considered that peach stem infections in California originate during outbreaks of the disease on leaves in late fall or early winter and that the fungus survives as mycelium in symptomless stems during the winter. In early spring, uredinia of the fungus rupture the epidermis of the stem to release urediniospores $(9,15)$. Barrett (2) noted that in mild climates the fungus may also survive on leaves through the winter. Thus, urediniospores from stem or leaf lesions may function as primary inoculum for infecting current-season leaves and developing fruit. However, in the central valley of California where peaches are commercially grown, leaves rarely remain on trees throughout the dormant season.

Peach rust can cause epidemics in highrainfall years $(8,9)$. When leaves are severely infected, premature defoliation may occur during the summer and early fall, reducing tree vigor or productivity in subsequent seasons. Furthermore, defoliation also creates difficulties in mechanical harvesting operations of canning peach (3). Fruit infections during late spring or early summer may result in direct economic losses to growers and canners (15). Duruz (7) indicated that commercial canneries reject peach fruit with rust lesions. In 1995, during a peach rust epidemic in Yuba City and Marysville, CA, canning peaches with three or more rust lesions were rejected by commercial canneries, and they were diverted to juice production (J. E. Adaskaveg, unpublished data).

The use of fungicides has been the main management strategy for controlling rust of peach and other stone fruit crops around the world $(5,11,22)$. Treatments 3,2 , and 1 month before harvest are applied when early-season disease outbreaks are common (3). When applied in early summer, fungicides prevent leaf and fruit infections on peach (15). These timings of treatments on peach have been based on currentseason disease observations or the historic occurrence of leaf or fruit symptoms in the orchard. No specific program for peach has been developed previously. Prior to 1998, sulfur compounds were the only fungicides registered in the United States for control of stone fruit rust. In California, applications of wettable sulfur or liquid lime sulfur have been effective in preventing leaf (25) and fruit (8) infections on peach and prune. Furthermore, applications of liquid lime sulfur in early fall have been suggested for managing the disease on leaves during late fall (7). Experimental in-season applications of ethylene bis-dithiocarbamates (EBDC), such as mancozeb or zineb, were effective in controlling rust on peaches (5) and prunes $(11,14)$. The sterol biosynthesis inhibiting (SBI) fungicides propiconazole $(11,22)$ and myclobutanil $(11,17,22)$ were also effective in managing the disease on prune and peach and on other stone fruits, respectively. These latter materials, in addition to other new classes of fungicides such as the strobilurins, have been registered for managing other diseases (e.g., brown rot) on stone fruits in the United States. Their efficacy against rust on California peach varieties and under California growing conditions has never before been evaluated. Thus, the purpose of this study was to test selected fungicides as alternatives to sulfur to prevent leaf and fruit infections during spring and summer and to determine optimum treatment timing while keeping the number of applications to a minimum. Because urediniospores of the fungus may overwinter on stems and, in mild climates, possibly on leaves, the efficacy of dormant treatments was also evaluated. 


\section{MATERIALS AND METHODS}

Evaluation of fungicides in the greenhouse. The efficacy of selected fungicides for reducing the severity of rust on leaves of potted cv. Lovell peach plants was evaluated in the greenhouse. Plants were grown from seed (Fowler Nurseries, Inc., Newcastle, CA) in a greenhouse at 15 to $30^{\circ} \mathrm{C}$ (maintained year round) and were pruned frequently to keep a height of 40 to $50 \mathrm{~cm}$. Urediniospores of $T$. discolor (designated as isolate R-96) were collected from leaves of cling peach (cv. Ross) in a commercial orchard in Marysville, CA, and the isolate was maintained on leaves of Lovell peach plants in the greenhouse. Fungicides and rates used are shown in Table 1. Fungicides were applied to run-off at the equivalent of 3,741 liter/ha. Leaves were sprayed on both sides with a selected fungicide using an atomizer (Model 15RD, DeVilbiss Health Care, Somerset, PA). Plants were air-dried and then inoculated by atomizing an aqueous suspension of urediniospores $\left(10^{5}\right.$ spores per $\left.\mathrm{ml}\right)$ collected from diseased greenhouse plants. To obtain a uniform urediniospore age, urediniospores from diseased leaves were washed off 4 days before preparing urediniospore inoculum for experiments. Inoculum was prepared using sterile distilled water containing $0.01 \%$ of Tween- 20 (polyoxyethylene sorbitan monolaurate). Plants were covered with clear plastic bags for $24 \mathrm{~h}$ immediately after inoculation. To evaluate the postinfection activity of azoxystrobin, tebuconazole, and wettable sulfur, the fungicides were applied as described above at $24,48,72,96$, or $120 \mathrm{~h}$ after a 24 -h wetness period following inoculation. Treated plants were randomly distributed on the greenhouse bench and three single-plant replications were used for each treatment. Experiments were repeated once for both fungicide efficacy and postinfection activity studies. Disease severity (number of lesions per leaf) was evaluated 20 days after inoculation on five leaves (the fourth to eighth youngest leaves) per branch for each of the three single-plant replications. Nontreated, inoculated plants were used as controls. Phytotoxicity was also evaluated for each treatment as either present or not. Variances of treatments from repeated experiments were evaluated using Bartlett's test for homogeneity of variance. For the fungicide efficacy studies, means of each treatment were separated using Duncan's multiple-range test. For fungicide postinfection activity studies, $\log _{10^{-}}$ transformed disease severity data were evaluated using analysis of variance and linear regression procedures (SAS version 6.12, SAS Institute Inc., Cary, NC).

Monitoring for the development of rust stem lesions of peach and environmental parameters in the field. Monitoring for sporulating stem lesions was done each spring from 1996 to 1999. Cultivars and orchards under study were the same as those described below in which fungicide trials were conducted. Samples consisted of 40 randomly collected 1-year-old stems about $0.5 \mathrm{~m}$ long from ten control trees in each orchard every 14 to 30 days from February through October (approximately every 14 days from late March to early May). Stems were then evaluated microscopically for the presence of sporulating stem lesions caused by $T$. discolor. Fungicides in the trials described below were applied 7 to 14 days after stem lesions were first detected.

Temperature and precipitation were also monitored from April through June of each year. Temperature was recorded using two or three temperature sensors and a datalogger (Campbell Scientific Inc., Logan, UT) that were placed in the orchards. Precipitation records were obtained from the California Irrigation Management Information System (CIMIS) network for locations in Marysville and Yuba City, CA.

Evaluation of dormant and in-season protective fungicide treatments in the field. In two commercial cling peach orchards (cvs. Andross and Ross) in Marysville, CA, chemical treatments and their timing were evaluated in 1996 and 1997. Fungicides and an agricultural oil as well as the rates used are listed in Table 1. Treatments were evaluated as dormant or spring applications, or both. Dormant applications that were done in late December of 1995 and 1996 included chlorothalonil and thiophanate-methyl/oil on cv. Andross and liquid lime sulfur on cv. Ross. Spring applications in 1996 and 1997 on both varieties included chlorothalonil/thiophanate-methyl/oil, myclobutanil, oil, propiconazole, tebuconazole, triforine, and wettable sulfur. Four different timings were evaluated each year. Timings included the following: after stem lesion detection (ASLD), ASLD and before the first forecasted rain, before the second forecasted rain, or before the first and second forecasted rains. Dates of application were 10 April (ASLD), 3 May (before first forecasted rain), and 23 May (before second forecasted rain) in 1996 and 14 April (ASLD), 16 May (before first forecasted rain), and 29 May (before second forecasted rain) in 1997. Timing of fungicide applications was also based on the assumption of a 2-week residual efficacy. In the before-the-first-and-second-forecasted-rains treatment for example, a fungicide was applied before the first forecasted rain after stem lesion detection and $\geq 2$ weeks later. In both years, dormant and spring treatments were arranged in a split-split-plot design. The main plots were dormant treatments arranged in randomized blocks. Subplots were fungicide-timing regimens and sub-subplots were randomized fungicide treatments. Four single-tree replications were used for each combination of dormant treatment, timing, and fungicide. Nontreated trees were used as controls. All treatments were applied using an air-blast sprayer calibrated for 935 liter/ha.

Evaluation of in-season protective and postinfection fungicide treatments in the field. In the spring of 1998 and 1999, azoxystrobin, tebuconazole, and wettable sulfur were applied to cv. Andross in two commercial orchards. Based on rain events and stem lesion detection, four different timings were evaluated in 1998. These were: ASLD, ASLD and after the first rain, after the first rain, and after the first and second rains. Timing of fungicide applications was again based on the assumption of a 2-week residual efficacy, as described in the previous paragraph. Thus, counting of rain events (e.g., after the first and second rain) was initiated after a 2 -week interval from fungicide application. Dates of application were 15 April, 9 May, and 1 June for ASLD, after the first rain, and after the second rain, respectively. In 1999, three timings (ASLD, after the first rain, and ASLD and after the first rain) were evaluated and applied on 30 April (ASLD) and 4 June (after first rain). Treatments were arranged in a split-plot design in which the main plots were fungicide application timings and the subplots were the fungicides. Four or five single-tree replications were

Table 1. Chemical treatments and rates evaluated for management of rust of cling peach in greenhouse and field trials

\begin{tabular}{|c|c|c|c|c|}
\hline \multirow[b]{2}{*}{ Common name } & \multirow[b]{2}{*}{ Trade name } & \multicolumn{2}{|c|}{ Rates (kg a.i./ha) } & \multirow{2}{*}{$\begin{array}{c}\text { Field application } \\
\text { timing }\end{array}$} \\
\hline & & Greenhouse & Field $^{y}$ & \\
\hline Azoxystrobin & Abound $2 \mathrm{~F}$ & 0.29 & 0.29 & Spring \\
\hline Benomyl & Benlate 50W & 1.1 & & $\ldots$ \\
\hline Chlorothalonil & Bravo 720 & 1.84 & 3.37 & Dormant/spring \\
\hline Liquid lime sulfur & Lime-sulfur solution & $\ldots^{\mathrm{z}}$ & 1.12 & Dormant \\
\hline Myclobutanil & Rally $40 \mathrm{~W}$ & 0.17 & 0.17 & Spring \\
\hline Oil & Omni Supreme Spray Oil & $\ldots$ & $2 \% \mathrm{vol} / \mathrm{vol}$ & Spring \\
\hline Propiconazole & Orbit 3.6EC & $\ldots$ & 0.13 & Spring \\
\hline Tebuconazole & Elite $45 \mathrm{DF}$ & 0.16 & 0.25 & Spring \\
\hline Thiophanate-methyl & Topsin 75WP & $\ldots$ & 1.12 & Dormant/spring \\
\hline Triforine & Funginex & $\ldots$ & 0.41 & Spring \\
\hline Wettable sulfur & Microthiol & 22.4 & 22.44 & Spring \\
\hline
\end{tabular}

${ }^{\mathrm{y}}$ In field applications, treatments were applied in water, using an air-blast sprayer at a rate of 935 liter/ha.

z $\ldots=$ Not done. 
used for each treatment combination (e.g., timing and fungicide). Nontreated trees were used as controls. Additionally, during these 2 years, grower applications of the three fungicides were compared with nontreated trees in another two commercial cv. Andross orchards. For this, five randomized replicated blocks of trees (3 rows $\times 100$ trees) were used for each treatment. Two trees were randomly sampled from the middle row of each replication of each treatment for disease evaluation. Two nontreated rows between treated blocks were the controls and five trees were randomly sampled from each row for disease evaluation. Rates of fungicides and timings of applications were the same as those evaluated in the experimental plots.

Disease evaluation. In all field trials, rust incidence on leaves and fruit was evaluated in the summer (last week of July or first week of August) to determine the efficacy of treatments. For these evaluations, a total of 100 to 300 leaves and 50 to 100 fruit per replication of each treatment were randomly sampled from four quadrants of each tree (up to $2.5 \mathrm{~m}$ high). Leaves and fruit with at least one rust lesion were considered diseased. Percentage of disease incidence on leaves and fruit was transformed using the arcsine squareroot transformation. Data were evaluated using an analysis of variance. Means of each treatment were separated using Duncan's multiple range test of SAS.

\section{RESULTS}

Evaluation of fungicides in the greenhouse. Results of greenhouse experiments showed that all fungicides tested significantly reduced the average number of rust lesions on leaves compared with that on the control (Fig. 1). Variances of treatments were homogeneous for combined experiments using nontransformed data.

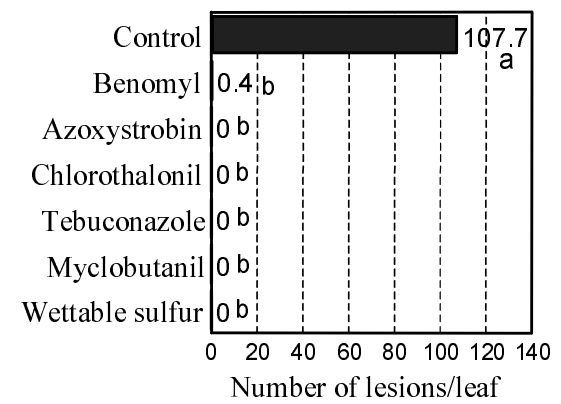

Fig. 1. Efficacy of fungicide applications in reducing rust incidence on peach leaves of potted plants in a greenhouse. Leaves were sprayed with fungicides using an atomizer, were air dried, and were inoculated with a spore suspension $\left(10^{5}\right.$ urediniospores per $\left.\mathrm{ml}\right)$ of Tranzschelia discolor. Disease severity was evaluated 20 days after inoculation and was based on the average number of lesions on five leaves for each of three single-plant replications for each treatment. Bars with the same letter are not significantly different, based on Duncan's multiple range test $(P=0.05)$.
Plants treated with azoxystrobin, chlorothalonil, myclobutanil, tebuconazole, or wettable sulfur did not develop any rust lesions. An average of only 0.4 lesions per leaf developed on plants sprayed with benomyl; however, there was no significant difference among the fungicide treatments. Nontreated plants had an average of 107.7 lesions per leaf. Chlorothalonil was the only fungicide that was phytotoxic to the peach leaves in these studies. Symptoms were small (approximately 3 to $5 \mathrm{~mm}$ in diameter) brown lesions that were randomly distributed over the leaf surface.

In studies to suppress disease, postinoculation applications with azoxystrobin and tebuconazole were effective in both experiments. Variances of treatments for both experiments were homogeneous only with transformed data. The regression models of disease severity $\left(\log _{10}\right.$ of number of lesions per leaf) on postinoculation application interval ( 24 to $120 \mathrm{~h}$ ) of azoxystrobin and tebuconazole were highly significant $(P<0.0002$ and $P<0.0183$, respectively), linear with positive slopes, and had coefficients of determination $\left(R^{2}\right)$ of 0.99 and 0.88 , respectively (Fig. 2). The number of lesions per leaf increased as the interval of application increased. For azoxystrobin, 0.4 and 33.1 lesions per leaf were observed in the 24- and 120-h treatments, respectively. For tebuconazole, the number of lesions per leaf at these intervals was 0.13 and 8.4. Wettable sulfur did not show any postinfection activity. The number of lesions per leaf for this treatment was 190.3. On nontreated plants, an average of 197 lesions per leaf developed.

Monitoring for the development of rust stem lesions of peach and environmental parameters in the field. Stem lesions were detected within a 7- to 14-day period prior to the ASLD fungicide application date. Incidence of stems with sporulating lesions at the first sampling date when stem lesions were detected was 10 and $27 \%$ on 25 March 1997, 36.6 and 50\% on 26 March 1998 for the two orchards, respectively, and $3.3 \%$ on 21 April 1999 for one orchard only. In 1996, stem lesions were found on 30 March, but the percentage of stems with lesions was not determined. Climatic conditions at test sites in Marysville, CA, and timing of fungicide applications for in-season protective treatments in 1996 and 1997 are shown in Figures $3 \mathrm{~A}$ and $\mathrm{B}$ and $3 \mathrm{C}$ and $\mathrm{D}$, respectively. Climatic conditions at test sites in Yuba City and Live Oak, CA, and timing of fungicide applications for in-season protective and postinfection treatments in 1998 and 1999 are shown in Figure $3 \mathrm{E}$ and $\mathrm{F}$ and Figure $3 \mathrm{G}$ and $\mathrm{H}$, respectively. Average temperatures were similar for all orchard sites.

Evaluation of dormant and in-season protective fungicide treatments in the field. On cv. Andross, the split-split-plot analysis of variance indicated that there were no significant differences among the control and the dormant treatments (chlorothalonil or thiophanate-methyl/oil), using the appropriate error term $(\mathrm{R} \times \mathrm{D})$ for the dormant treatment, in reducing the incidence of rust on leaves and fruit in 1996 and 1997 (Table 2). There were, however, significant differences between fungicide application timing treatments during the spring (e.g., T or subplot), using the appropriate error variance $[\mathrm{R} \times \mathrm{T}(\mathrm{D})]$, in reducing the incidence of rust on leaves in 1996 and 1997 but not on fruit in 1996 (Tables 2 and 3). No fruit disease was observed in 1997. Significant differences

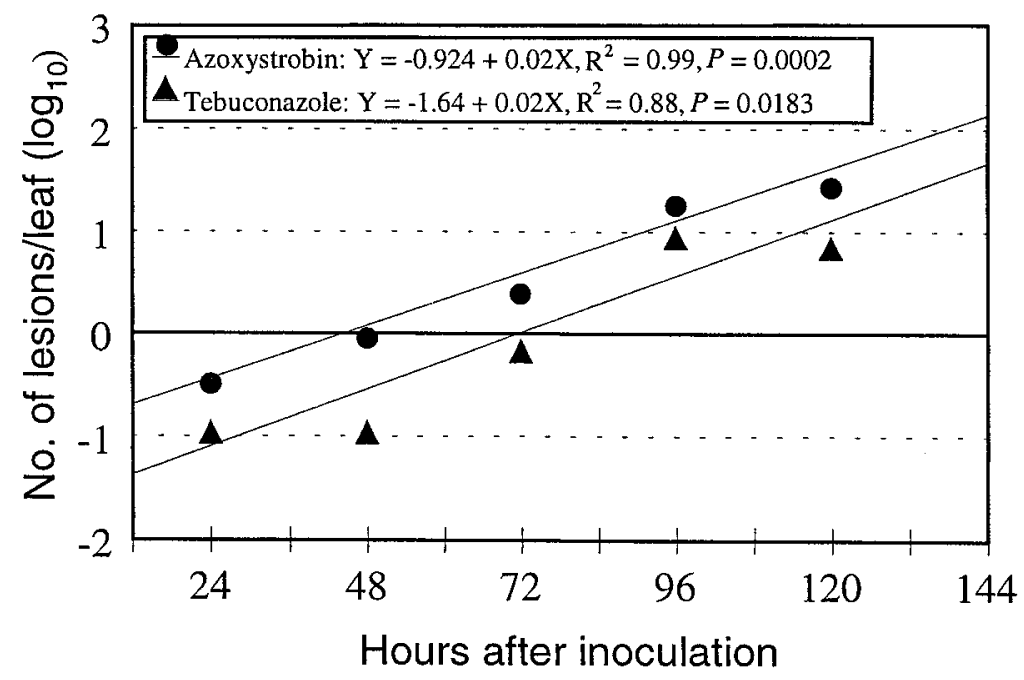

Fig. 2. Regression of time of azoxystrobin and tebuconazole application after inoculation of Tranzschelia discolor on $\log _{10}$-transformed average numbers of lesions per leaf of peach rust in a greenhouse experiment. Leaves were inoculated with a spore suspension $\left(10^{5}\right.$ urediniospores per ml), were covered with plastic bags for $24 \mathrm{~h}$, and were sprayed to run-off with azoxystrobin (Abound 2F, 1.2 liter/ha) and tebuconazole (Elite $45 \mathrm{DF}, 0.35 \mathrm{~kg} / \mathrm{ha}$ ) 24, 48, 72, 96, or $120 \mathrm{~h}$ after inoculation. Disease severity was evaluated 20 days after inoculation based on the mean of five leaves for each of three single-plant replications for each treatment. On nontreated plants, an average of 197 lesions per leaf developed. 
were observed for the sub-subplot or fungicide treatments (Trt) for both leaves and fruit in both years (Table 2). In 1996, however, the average disease on controls was too low $(0.33 \%)$ to make valid comparisons. Because there was a significant interaction between timing and fungicide treatments $(\mathrm{T} \times \mathrm{Trt})$, fungicide treatments by time of application were compared for their effectiveness in reducing rust incidence on leaves. Differences among treatments were observed for all timings (Table 3). Rust incidence on leaves was significantly lower for all fungicide treatments $(\leq 1.7 \%)$ than for the controls in both years when disease ranged from 5.0 to $7.8 \%$. In general, oil applications were the least effective, regardless of timing.

In the analysis of variance for rust incidence on leaves and fruit of cv. Ross, no significant differences between the control and the liquid lime sulfur dormant treatment (e.g., D or main plot) were observed using the appropriate error term $\mathrm{R} \times \mathrm{D}$ for leaves and fruit in 1996 and 1997 (Table 4). Significant differences between fungicide application timings during the spring (e.g., T or subplot) were observed, using the appropriate error term $(\mathrm{R} \times \mathrm{T}(\mathrm{D}))$ in reducing the incidence of rust on leaves in 1997 and fruit in 1996 but not on leaves in 1996 (Tables 4 and 5). No interactions were observed between timing and fungicide treatments $(\mathrm{T} \times \mathrm{Trt})$, and no fruit disease was observed in 1997. There were highly significant differences among treatments (Trt) on leaves in 1996 and 1997 and on fruit in 1996. In 1996, the maximum disease incidence on leaves was only $0.6 \%$ and thus, no comparisons of treatment means were done. Unlike data obtained on cv. Andross, only some treatments on cv. Ross consistently lowered the disease for most application timings, as compared with controls in which disease ranged from 1.5 to $2.2 \%$ on leaves and 1.9 to $3.1 \%$ on fruit (Table 5). On fruit, applications of myclobutanil, propiconazole, or tebuconazole and, on leaves, applications of myclobutanil, tebuconazole, and chlorothalonil/thiophanate-methyl/oil treatments were consistently more effective in reducing disease incidence at each application time than the other treatments.

In 1996, a single application before the second forecasted rain or two applications at ASLD and before the first forecasted rain or at before the first and second forecasted rains were significantly better than a single application at ASLD on leaves of cv.
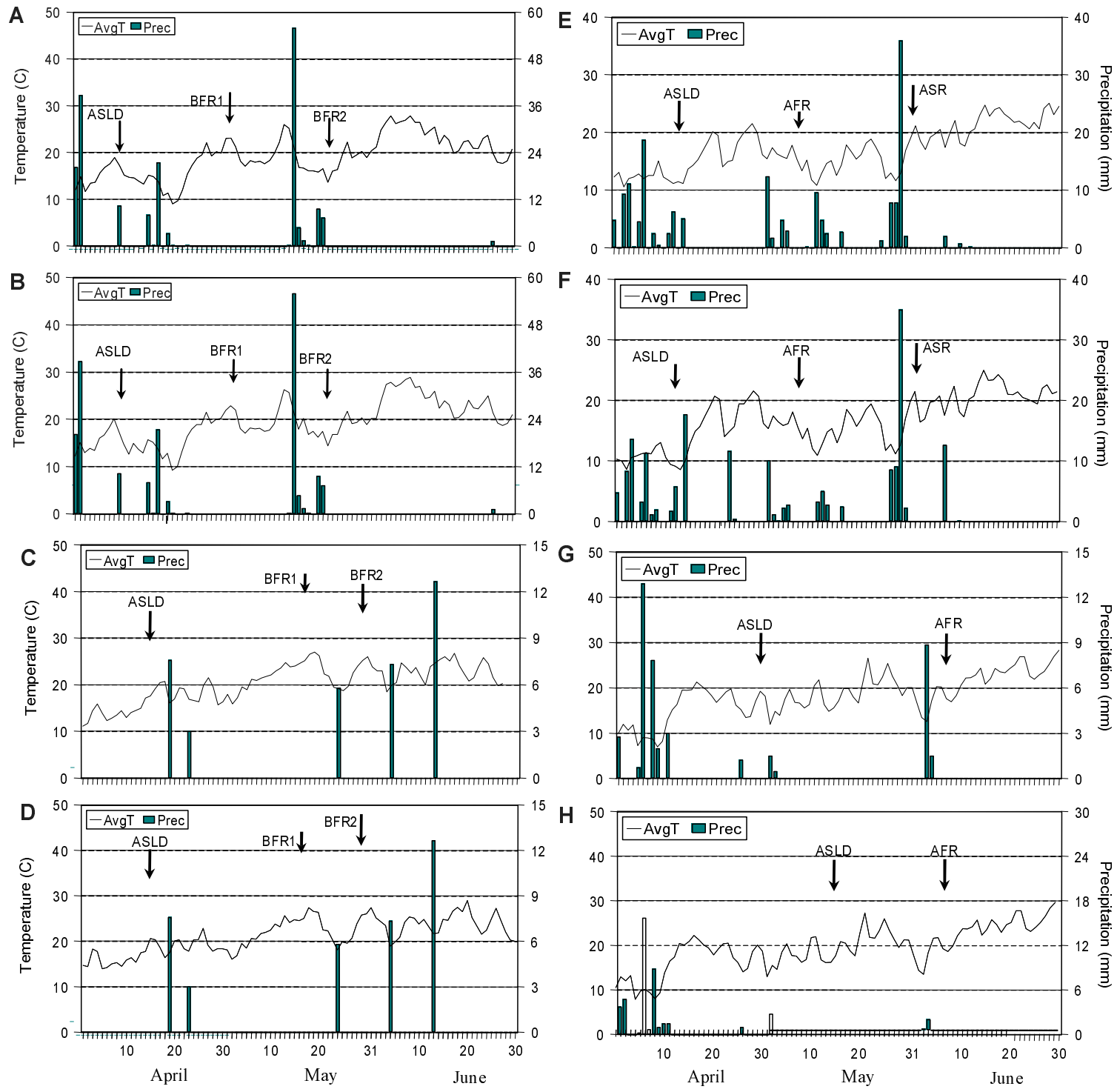

Fig. 3. Average daily temperature $\left({ }^{\circ} \mathrm{C}\right)$ and precipitation (mm) from April through June 1996 to 1999. In 1996 to 1997, data were collected from a cling peach orchard A and C, cv. Andross and B and D, cv. Ross in Marysville, CA. Dates of treatment applications: 10 April, 3 May, and 23 May, 1996 and 14 April, 16 May, and 29 May, 1997. In 1998 to 1999, data were collected from a cling peach orchard $\mathbf{E}$ and $\mathbf{G}$, cv. Andross in Yuba City and $\mathbf{F}$ and $\mathbf{H}$, cv. Ross in Live Oak, CA. Dates of applications: 15 April, 9 May, and 1 June 1998 and 30 April and 4 June 1999. Temperatures were recorded using a datalogger equipped with temperature sensors. Precipitation was obtained from the California Irrigation Management Information System network. Abbreviations: ASLD = after stem lesion detection, BFR1 = before the first forecasted rain, BFR2 = before the second forecasted rain, AFR $=$ after first rain, ASR $=$ after second rain, $\operatorname{Avg} \mathrm{T}=$ average temperature, and Prec $=$ precipitation . 
Andross (Table 3). On fruit of cv. Ross, a single application before the second forecasted rain had results similar to those of the two-application timing strategies (Table 5). In 1997, one application at ASLD or two applications (ASLD and before the first forecasted rain) were more effective than later season applications (before the second forecasted rain or before the first and second forecasted rains) on leaves of cv. Andross (Table 3). On leaves of cv. Ross in 1997, the ASLD and before-thefirst-forecasted-rain timing had significantly less disease than the before-thesecond-forecasted-rain timing (Table 5). The other timings formed statistically intermediate groups.

Evaluation of in-season protective and postinfection fungicide treatments in the field. In 1998, highly significant differences among fungicide treatments and their timing were observed in rust incidence on leaves of cv. Andross (Table 6). On fruit, highly significant differences were observed only among treatments. In 1999, there were significant differences only among treatments on leaves. In both years, no interactions were observed between timing and fungicide treatments (T $\times$ Trt) for leaf or fruit data. No fruit symptoms were found in 1999.

In both 1998 and 1999, the three fungicides tested significantly reduced the disease on both plant tissues compared with that on the controls (Table 7). Rust incidence was higher on leaves than on fruit on nontreated trees. Disease incidence on leaves of nontreated trees ranged from 45.1 to $53.7 \%$ in 1998 and from 0.7 to $2.0 \%$ in 1999. On leaves in 1998, a single application of azoxystrobin at ASLD or one or two applications of tebuconazole, regardless of timing, reduced disease incidence significantly to zero or near-zero $(0.4 \%)$ levels compared with that of the wettable sulfur and the control treatments. Applications of azoxystrobin and wettable sulfur after the first rain or after the first and second rains were significantly less effective than the tebuconazole treatment at any timing. On fruit, a single application of azoxystrobin or tebuconazole made at ASLD or two applications after the first and second rains significantly lowered disease incidence, as compared with that of the sulfur and control treatments. On leaves, a comparison of timings of fungi-

Table 2. Analysis of variance for rust disease incidence on leaves and fruit of cling peach cv. Andross in 1996 and 1997 in Marysville, CA

\begin{tabular}{|c|c|c|c|c|c|c|}
\hline \multirow[b]{2}{*}{ Year } & \multirow[b]{2}{*}{ Source } & \multirow[b]{2}{*}{ df } & \multicolumn{4}{|c|}{ Leaf/fruit ${ }^{w}$} \\
\hline & & & Sum square & Mean square & $F$ value & $P>F^{x}$ \\
\hline \multirow{10}{*}{1996} & Replication (R) & 3 & $458.93 / 11.53$ & $152.98 / 3.84$ & & \\
\hline & Dormant $(\mathrm{D})^{\mathrm{y}}$ & 2 & $69.76 / 1.38$ & $34.88 / 0.69$ & $0.51 / 0.75$ & $\mathrm{~ns} / \mathrm{ns}$ \\
\hline & $\mathrm{R} \times \mathrm{D}$ & 6 & $409.15 / 5.51$ & 68.19/0.92 & & \\
\hline & Timing $(T)^{z}$ & 3 & $479.35 / 1.89$ & $159.78 / 0.63$ & $9.82 / 0.33$ & $0.0002 / \mathrm{ns}$ \\
\hline & $\mathrm{D} \times \mathrm{T}^{\mathrm{z}}$ & 6 & $81.66 / 15.15$ & $13.61 / 2.52$ & $0.84 / 1.33$ & $\mathrm{~ns} / \mathrm{ns}$ \\
\hline & $\mathrm{R} \times \mathrm{T}(\mathrm{D})$ & 27 & $439.44 / 51.12$ & $16.28 / 1.89$ & & \\
\hline & Treatment (Trt) & 7 & $5857.20 / 52.16$ & $836.74 / 7.45$ & $95.57 / 4.23$ & $0.0001 / 0.0002$ \\
\hline & $\mathrm{D} \times \mathrm{Trt}$ & 14 & $104.26 / 20.66$ & $7.45 / 1.48$ & $0.85 / 0.84$ & $\mathrm{~ns} / \mathrm{ns}$ \\
\hline & $\mathrm{T} \times \operatorname{Trt}$ & 21 & $315.86 / 18.76$ & $15.04 / 0.89$ & $1.72 / 0.51$ & $0.0285 / \mathrm{ns}$ \\
\hline & $\mathrm{D} \times \mathrm{T} \times \mathrm{Trt}$ & 42 & $597.04 / 84.00$ & $14.22 / 2.00$ & $1.62 / 1.13$ & $0.013 / \mathrm{ns}$ \\
\hline \multirow[t]{10}{*}{1997} & Replication (R) & 4 & 258.53/--- & 64.63/--- & & \\
\hline & Dormant $(\mathrm{D})^{\mathrm{y}}$ & 1 & 21.80/--- & 21.80/--- & $0.32 /---$ & ns/--- \\
\hline & $\mathrm{R} \times \mathrm{D}$ & 3 & 204.30/--- & 68.10/--- & & \\
\hline & Timing $(\mathrm{T})^{\mathrm{z}}$ & 3 & 426.45/--- & 142.15/--- & 13.61/--- & 0.0001/--- \\
\hline & $\mathrm{D} \times \mathrm{T}^{\mathrm{z}}$ & 3 & 39.65/--- & 13.22/--- & $1.26 /---$ & ns/--- \\
\hline & $\mathrm{R} \times \mathrm{T}(\mathrm{D})$ & 21 & 219.39/--- & 10.45/--- & & \\
\hline & Treatment (Trt) & 7 & 3261.41/--- & 465.92/--- & 58.84/--- & 0.0001/--- \\
\hline & $\mathrm{D} \times \operatorname{Trt}$ & 7 & 57.53/--- & 8.22/--- & 1.04/--- & ns/--- \\
\hline & $\mathrm{T} \times \mathrm{Trt}$ & 21 & 313.79/--- & 14.94/--- & 1.89/--- & 0.0136/--- \\
\hline & $\mathrm{D} \times \mathrm{T} \times \mathrm{Trt}$ & 21 & 103.53/--- & 4.93/--- & $0.62 /---$ & ns/--- \\
\hline
\end{tabular}

${ }^{\mathrm{w}}$ Statistical values presented are based on leaf or fruit samples (leaf/fruit). Dashed lines $(---)=$ no disease data.

${ }^{\mathrm{x}}$ Levels of significance: highly significant $(P<0.01)$, significant $(P<0.10)$, and ns $=$ not significant $(P>0.10)$.

${ }^{\mathrm{y}}$ Test of hypothesis using ANOVA mean square (MS) for $\mathrm{R} \times \mathrm{D}$ as an error term.

${ }^{\mathrm{z}}$ Test of hypothesis using ANOVA mean square (MS) for $\mathrm{R} \times \mathrm{T}(\mathrm{D})$ as an error term.

Table 3. Efficacy of treatments and application timings on reducing rust incidence on leaves of cling peach cv. Andross in the spring of 1996 and 1997 in Marysville, CA

\begin{tabular}{|c|c|c|c|c|c|c|c|c|}
\hline \multirow[b]{3}{*}{ Treatments $^{\mathrm{z}}$} & \multicolumn{8}{|c|}{ Disease incidence $(\%)^{y}$} \\
\hline & \multicolumn{2}{|c|}{ ASLD } & \multicolumn{2}{|c|}{ BFR2 } & \multicolumn{2}{|c|}{ ASLD/BFR1 } & \multicolumn{2}{|c|}{ BFR1/BFR2 } \\
\hline & 1996 & 1997 & 1996 & 1997 & 1996 & 1997 & 1996 & 1997 \\
\hline Control & $7.8 \mathrm{a}$ & $5.0 \mathrm{a}$ & $6.4 \mathrm{a}$ & $6.6 \mathrm{a}$ & $6.1 \mathrm{a}$ & $5.6 \mathrm{a}$ & $5.2 \mathrm{a}$ & $6.4 \mathrm{a}$ \\
\hline Chlorothalonil/thiophanate-methyl/oil & $0.5 \mathrm{c}$ & $0.3 \mathrm{c}$ & $0.4 \mathrm{c}$ & $1.3 \mathrm{bc}$ & $0.2 \mathrm{c}$ & $0.2 \mathrm{c}$ & $0.4 \mathrm{bc}$ & $1.3 \mathrm{~b}$ \\
\hline Oil & $1.7 \mathrm{~b}$ & $1.0 \mathrm{bc}$ & $1.2 \mathrm{~b}$ & $1.9 \mathrm{~b}$ & $1.2 \mathrm{~b}$ & $0.5 \mathrm{bc}$ & $1.2 \mathrm{~b}$ & $1.0 \mathrm{bc}$ \\
\hline Myclobutanil & $1.0 \mathrm{bc}$ & $0.2 \mathrm{c}$ & $0.0 \mathrm{c}$ & $1.0 \mathrm{~cd}$ & $0.5 \mathrm{bc}$ & $0.2 \mathrm{c}$ & $0.0 \mathrm{c}$ & $0.2 \mathrm{c}$ \\
\hline Propiconazole & $1.1 \mathrm{bc}$ & $1.4 \mathrm{~b}$ & $0.3 \mathrm{c}$ & $1.4 \mathrm{bc}$ & $0.2 \mathrm{c}$ & $0.8 \mathrm{~b}$ & $0.2 \mathrm{c}$ & $1.3 \mathrm{~b}$ \\
\hline Tebuconazole & $0.7 \mathrm{bc}$ & $0.3 \mathrm{c}$ & $0.1 \mathrm{c}$ & $0.5 \mathrm{~d}$ & $0.6 \mathrm{bc}$ & $0.3 \mathrm{bc}$ & $0.4 \mathrm{bc}$ & $0.2 \mathrm{c}$ \\
\hline Triforine & $1.5 \mathrm{bc}$ & $0.2 \mathrm{c}$ & $1.0 \mathrm{~b}$ & $1.6 \mathrm{bc}$ & $0.5 \mathrm{bc}$ & $0.2 \mathrm{c}$ & $0.5 \mathrm{bc}$ & $1.1 \mathrm{bc}$ \\
\hline Wettable sulfur & $1.7 \mathrm{~b}$ & $0.1 \mathrm{c}$ & $0.2 \mathrm{c}$ & $1.4 \mathrm{bc}$ & $0.2 \mathrm{c}$ & $0.1 \mathrm{c}$ & $0.1 \mathrm{c}$ & $1.1 \mathrm{~b}$ \\
\hline Spray timing-1996 & $2.0 \mathrm{~A}$ & & $1.2 \mathrm{~B}$ & & $1.2 \mathrm{~B}$ & & $1.0 \mathrm{~B}$ & \\
\hline Spray timing-1997 & & $1.1 \mathrm{~B}$ & & $1.9 \mathrm{~A}$ & & $1.0 \mathrm{~B}$ & & $1.6 \mathrm{~A}$ \\
\hline
\end{tabular}

y Disease incidence was based on 200 leaves for each of four single-tree replications per treatment in 1996 and 300 leaves for each of four or five single tree replications per treatment in 1997. Means followed by the same letter are not significantly different according to Duncan's multiple range test $(P>$ 0.05). Treatment comparisons are by column, whereas comparisons of timing of application are by row.

${ }^{\mathrm{z}}$ Treatments were applied after stem lesion detection (ASLD) on 10 April, before the first forecasted rain (BFR1) on 3 May, and before the second forecasted rain (BFR2) on 23 May in 1996, and on 14 April (ASLD), 16 May (BFR1), and 29 May (BFR2) in 1997. For the chlorothalonil/thiophanatemethyl/oil treatment, chlorothalonil was applied ASLD, whereas thiophanate-methyl/oil was applied BFR1 and BFR2. 
cide treatments indicated that the ASLD and the ASLD-and-after-the-first-rain timings had significantly lower disease incidence as compared with a treatment after the first rain or after-the-first-and-second-rain timings. No significant differences in treatment timings were observed on fruit in 1998 or leaves in 1999. In 1999, however, all fungicide treatments at all timings significantly reduced incidence of rust to zero levels as compared with the control (Table 7).

Grower applications of fungicides were effective in reducing the incidence of rust in 1998 and 1999. In 1998, applications of tebuconazole and azoxystrobin reduced the disease on leaves to 0.3 and $0.0 \%$, respectively, compared to $9.8 \%$ incidence on leaves of nontreated controls. In 1999, azoxystrobin, tebuconazole, and wettable sulfur reduced the disease to zero levels, whereas the control had $4 \%$ disease incidence.

\section{DISCUSSION}

Efficacy data obtained in our studies were used to support label changes for myclobutanil, tebuconazole, propiconazole, and azoxystrobin to include management of peach rust caused by $T$. discolor in the United States. This is the first time that alternative and rotational treatments to sulfur have been developed and registered on peach and other stone fruit crops in California for this disease.. Our greenhouse and field studies demonstrated that peach

Table 4. Analysis of variance for rust disease incidence on leaves and fruit of cling peach cv. Ross in 1996 and 1997 in Marysville, CA

\begin{tabular}{|c|c|c|c|c|c|c|}
\hline \multirow[b]{2}{*}{ Year } & \multirow[b]{2}{*}{ Source } & \multicolumn{5}{|c|}{ Leaf/fruit $^{w}$} \\
\hline & & df & Sum square & Mean square & $F$ value & $P>F^{\mathbf{x}}$ \\
\hline \multirow[t]{10}{*}{1996} & Replication (R) & 3 & $2.90 / 345.3$ & $0.97 / 115.12$ & & \\
\hline & Dormant $(\mathrm{D})^{\mathrm{y}}$ & 1 & $12.41 / 11.9$ & $12.41 / 11.96$ & $5.9 / 1.51$ & $\mathrm{~ns} / \mathrm{ns}$ \\
\hline & $\mathrm{R} \times \mathrm{D}$ & 3 & $6.31 / 23.82$ & $2.10 / 7.94$ & & \\
\hline & Timing $(\mathrm{T})^{\mathrm{z}}$ & 3 & $8.57 / 201.78$ & $2.86 / 67.26$ & $0.46 / 3.14$ & $\mathrm{~ns} / 0.0510$ \\
\hline & $\mathrm{D} \times \mathrm{T}^{\mathrm{z}}$ & 3 & $10.21 / 61.60$ & $3.40 / 20.53$ & $0.54 / 0.96$ & $\mathrm{~ns} / \mathrm{ns}$ \\
\hline & $\mathrm{R} \times \mathrm{T}(\mathrm{D})$ & 18 & $112.62 / 385.78$ & $6.26 / 21.43$ & & \\
\hline & Treatment (Trt) & 7 & $149.76 /$ & $21.39 / 112.19$ & $5.05 / 8.46$ & $0.0001 / 0.0001$ \\
\hline & D $\times$ Trt & 7 & $22.41 / 48.22$ & $3.20 / 6.89$ & $0.76 / 0.52$ & $\mathrm{~ns} / \mathrm{ns}$ \\
\hline & TxTrt & 21 & $123.02 / 353.64$ & $5.86 / 16.84$ & $1.38 / 1.27$ & $\mathrm{~ns} / \mathrm{ns}$ \\
\hline & $\mathrm{D} \times \mathrm{T} \times \mathrm{Trt}$ & 21 & $84.33 / 356.50$ & $4.02 / 16.98$ & $0.95 / 1.28$ & $\mathrm{~ns} / \mathrm{ns}$ \\
\hline \multirow[t]{10}{*}{1997} & Replication(R) & 3 & 255.18/--- & 85.06/--- & & \\
\hline & Dormant (D) ${ }^{\mathrm{y}}$ & 1 & 97.27/--- & 97.27/--- & 1.82/--- & ns/--- \\
\hline & $\mathrm{R} \times \mathrm{D}$ & 3 & 160.02/--- & 53.34/--- & & \\
\hline & Timing $(\mathrm{T})^{\mathrm{z}}$ & 3 & 156.99/--- & 52.33/--- & 3.81/--- & 0.0282/--- \\
\hline & $\mathrm{D} \times \mathrm{T}^{\mathrm{z}}$ & 3 & 50.03/--- & 16.68/--- & 1.21/--- & ns/--- \\
\hline & $\mathrm{R} \times \mathrm{T}(\mathrm{D})$ & 18 & 247.13/--- & 13.73/--- & & \\
\hline & Treatment (Trt) & 7 & 393.13/--- & 56.16/--- & 7.99/--- & 0.0001/--- \\
\hline & D $\times$ Trt & 7 & 18.96/--- & 2.71/--- & 0.39/--- & ns/--- \\
\hline & TxTrt & 21 & 155.09/--- & 7.39/--- & 1.05/--- & ns/--- \\
\hline & $\mathrm{D} \times \mathrm{T} \times \mathrm{Trt}$ & 21 & 168.60/--- & 8.03/--- & 1.14/--- & ns/--- \\
\hline
\end{tabular}

${ }^{\mathrm{w}}$ Statistical values are based on leaf or fruit samples (leaf/fruit). Dashed lines $(---)=$ no disease data.

${ }^{\mathrm{x}}$ Levels of significance: highly significant $(P<0.01)$, significant $(P<0.10)$, and ns $=$ not significant $(P>0.10)$.

${ }^{y}$ Test of hypothesis using ANOVA mean square (MS) for $\mathrm{R} \times \mathrm{D}$ as an error term.

${ }^{\mathrm{z}}$ Test of hypothesis using ANOVA mean square (MS) for $\mathrm{R} \times \mathrm{T}(\mathrm{D})$ as an error term. rust can be effectively managed with protective foliar applications of benzimidazole (e.g., benomyl, thiophanate-methyl), SBI (e.g., myclobutanil, propiconazole, tebuconazole), and strobilurin (e.g., azoxystrobin) fungicides. These fungicides were all highly effective regardless of inseason timing in reducing rust on peach leaves and fruit in years when the disease developed on nontreated control trees. The efficacy in most years was similar to or better than wettable sulfur. Furthermore, in a year conducive to disease on foliage and fruit (e.g., 1998), single applications of azoxystrobin or tebuconazole ASLD were significantly more efficacious than sulfur (Table 7). EBDC $(5,11,14)$, SBI $(12)$, and strobilurin (20) fungicides have been used successfully in other countries to manage prune rust. Wettable sulfur has been used in California as a standard treatment for managing rust, because it is effective and inexpensive $(8,15)$. Sulfur products, however, are skin and eye irritants to workers involved in orchard cultivation practices, such as fruit thinning, pruning, or harvesting. In view of these concerns, the availability of SBI and strobilurin fungicides provides highly effective alternatives and rotational complements to sulfur.

In greenhouse studies, chlorothalonil was also highly effective as a protective foliar treatment in preventing peach rust. Duan et al. (6) showed chlorothalonil to be highly inhibitory in laboratory germination tests using urediniospores of $T$. discolor from peach. Because of label restrictions that limit applications of this fungicide to petal fall treatments in the field, the rotational program of chlorothalonil with thiophanate methyl-oil was used in our field studies and was also shown to be effective. Benomyl and thiophanate-methyl were also effective against the disease. These fungicides have been registered on peach for other diseases in California. Because of

Table 5. Efficacy of treatments and application timings on reducing rust incidence on fruit and leaves of cling peach cv. Ross in the spring of 1996 and 1997 in Marysville, CA

\begin{tabular}{|c|c|c|c|c|c|c|c|c|}
\hline \multirow[b]{3}{*}{ Treatment $^{\mathrm{z}}$} & \multicolumn{8}{|c|}{ Disease incidence $(\%)^{y}$} \\
\hline & \multicolumn{2}{|c|}{ ASLD } & \multicolumn{2}{|c|}{ BFR2 } & \multicolumn{2}{|c|}{ ASLD/BFR1 } & \multicolumn{2}{|c|}{ BFR1/BFR2 } \\
\hline & Fruit 1996 & Leaf 1997 & Fruit 1996 & Leaf 1997 & Fruit 1996 & Leaf 1997 & Fruit 1996 & Leaf 1997 \\
\hline Control & $3.1 \mathrm{a}$ & $2.0 \mathrm{a}$ & $1.3 \mathrm{ab}$ & $2.2 \mathrm{a}$ & $1.9 \mathrm{a}$ & $1.5 \mathrm{a}$ & $2.1 \mathrm{a}$ & $1.6 \mathrm{a}$ \\
\hline $\begin{array}{l}\text { Chlorothalonil/thiophanate- } \\
\text { methyl/oil }\end{array}$ & $0.1 \mathrm{c}$ & $0.5 \mathrm{~b}$ & $0.5 \mathrm{ab}$ & $0.5 \mathrm{bc}$ & $0.1 \mathrm{~b}$ & $0.3 \mathrm{~b}$ & $0.6 \mathrm{ab}$ & $0.8 \mathrm{a}$ \\
\hline Oil & $1.1 \mathrm{abc}$ & $0.8 \mathrm{ab}$ & $1.6 \mathrm{a}$ & $0.8 \mathrm{abc}$ & $0.9 \mathrm{ab}$ & $0.4 \mathrm{~b}$ & $1.4 \mathrm{ab}$ & $1.3 \mathrm{a}$ \\
\hline Myclobutanil & $0.9 \mathrm{abc}$ & $0.6 \mathrm{~b}$ & $0.1 \mathrm{~b}$ & $0.6 \mathrm{bc}$ & $0.1 \mathrm{~b}$ & $0.2 \mathrm{~b}$ & $0.3 \mathrm{~b}$ & $0.3 \mathrm{a}$ \\
\hline Propiconazole & $0.9 \mathrm{bc}$ & $1.0 \mathrm{ab}$ & $0.1 \mathrm{~b}$ & $1.3 \mathrm{abc}$ & $0.9 \mathrm{ab}$ & $0.6 \mathrm{ab}$ & $0.4 \mathrm{~b}$ & $0.7 \mathrm{a}$ \\
\hline Tebuconazole & $0.8 \mathrm{bc}$ & $0.2 \mathrm{~b}$ & $0.0 \mathrm{~b}$ & $0.4 \mathrm{c}$ & $0.4 \mathrm{~b}$ & $0.3 \mathrm{~b}$ & $0.5 \mathrm{ab}$ & $0.7 \mathrm{a}$ \\
\hline Triforine & $2.3 \mathrm{ab}$ & $0.3 \mathrm{~b}$ & $0.9 \mathrm{ab}$ & $1.5 \mathrm{ab}$ & $1.1 \mathrm{ab}$ & $0.2 \mathrm{~b}$ & $0.8 \mathrm{ab}$ & $0.7 \mathrm{a}$ \\
\hline Wettable sulfur & $2.3 \mathrm{a}$ & $0.4 \mathrm{~b}$ & $0.6 \mathrm{ab}$ & $1.2 \mathrm{ab}$ & $1.0 \mathrm{ab}$ & $0.2 \mathrm{~b}$ & $2.0 \mathrm{a}$ & $0.7 \mathrm{a}$ \\
\hline Spray timing_-1996 & $1.4 \mathrm{~A}$ & & $0.6 \mathrm{~B}$ & & $0.8 \mathrm{AB}$ & & $1.0 \mathrm{AB}$ & \\
\hline Spray timing_-1997 & & $0.7 \mathrm{AB}$ & & $1.1 \mathrm{~A}$ & & $0.5 \mathrm{~B}$ & & $0.8 \mathrm{AB}$ \\
\hline
\end{tabular}

y Disease incidence was based on 200 leaves for each of four single-tree replications per treatment in 1996 and 300 leaves for each of four of five singletree replications per treatment in 1997. Means followed by the same letter are not significantly different according to Duncan's multiple range test $(P>$ 0.05). Treatment comparisons are by column, whereas comparisons of timing of applications are by row.

${ }^{\mathrm{z}}$ Treatments were applied after stem lesion detection (ASLD) on 10 April, before the first forecasted rain (BFR1) on 3 May, and before the second forecasted rain (BFR2) on 23 May in 1996, and on 14 April (ASLD), 16 May (BFR1), and 29 May (BFR2) in 1997. For the chlorothalonil/thiophanatemethyl/oil treatment, chlorothalonil was applied ASLD, whereas thiophanate-methyl was applied BFR1 and BFR2. 
concerns of resistance developing in populations of the rust pathogen, as has occurred in other pathogen populations such as Monilinia spp. (16), label changes for the recently canceled benomyl or for thiophanate-methyl to include management of rust have not been considered or requested. Thus, the identification of SBI and azoxystrobin fungicides, which represent distinct classes of fungicides, as effective treatments for managing rust will allow the development of mixtures or rotation programs that minimize the potential for resistance to develop in target populations of stone fruit pathogens. The oil treatment was included in the evaluation because agricultural oils are known to be effective in reducing some diseases caused by biotrophic pathogens, such as powdery mildews (10). This treatment significantly reduced peach rust in our field studies, but the efficacy was generally lower than that of the conventional fungicides evaluated. Oil treatments, however, cannot be used in rotation with sulfur, due to phytotoxic interactions between the materials. Thus, the application of this treatment is restricted.

When dormant treatments of liquid lime sulfur, chlorothalonil, and thiophanatemethyl mixed with an agricultural oil were evaluated in 1996 and 1997 on two peach cultivars, they were ineffective in reducing the disease the following spring and summer season. Although disease incidence was low in these years, the split-split plot design allowed for this evaluation because of large sample sizes $(n=128)$ in trials with cv. Andross (2 degrees of freedom) and with cv. Ross (1 degree of freedom). The ineffectiveness of dormant treatments indicates that overwintering urediniospores on the plant surface are not likely sources of new infections in the spring. Furthermore, because stem lesions were detected in the spring in both trials and years, the dormant treatments probably did not prevent or eradicate existing stem infections during the winter. Liquid lime sulfur, chlorothalonil, or thiophanate-methyl/oil did not prevent stem lesion development on woody tissue in the spring. This also suggests that stem infections were probably initiated in the fall before application of the treatments (i.e., late December in 1995 and 1996 for 1996 and 1997 trials, respectively).

Timing of spring applications of fungicides was found to be a significant factor in reducing the incidence of rust on leaves and fruit in most trials and years (Tables 3 and 5). In the split-split plots, timing of fungicide application was evaluated in four programs based on monitoring 1-year-old peach stems for sporulating stem lesions and based on rain events. In 1996 and
1997, fungicide applications after stem lesion detection were made before forecasted rains, provided that a 2 -week interval had occurred after the previous fungicide application. With low disease incidence in these years, significant differences in application timing were still obtained, because the plot design had a large sample size for each application program $(n=64)$, with three degrees of freedom. On leaves of cv. Andross, the two-spray program, ASLD and before the first forecasted rain, consistently and significantly lowered disease incidence as compared with the ASLD timing in 1996 and the before-the-first-and-second-forecasted-rain and before-the-second-forecasted-rain timings in 1997. Similar trends were observed on leaves of cv. Ross in 1997. The low precipitation in 1996 could explain why no differences were observed among the twoapplication timings and before-the-secondforecasted-rain timing. These treatments were all significantly better than the single application after stem lesion detection. This latter application was made before a low-temperature rain (Fig. 3A and B) that was probably not conducive for fungal infection. Temperatures below $15^{\circ} \mathrm{C}$ are less conducive for stone fruit rust on prune (13). Potentially, our model could be further modified to limit fungicide applica-

Table 6. Analysis of variance for rust disease incidence on leaves and fruit of cling peach cv. Andross in 1998 and 1999 in Marysville, CA

\begin{tabular}{|c|c|c|c|c|c|c|c|}
\hline \multirow[b]{2}{*}{ Year } & \multirow[b]{2}{*}{ Tissue } & \multirow[b]{2}{*}{ Source } & \multirow[b]{2}{*}{ df } & \multicolumn{4}{|c|}{ Leaf/fruit $^{x}$} \\
\hline & & & & Sum square & Mean square & $F$ value & $P>F^{y}$ \\
\hline \multirow[t]{5}{*}{1998} & Leaf & Replication (R) & 4 & $1213.51 / 402.61$ & $303.38 / 100.65$ & & \\
\hline & & Timing $(\mathrm{T})^{\mathrm{z}}$ & 3 & $890.37 / 125.06$ & $296.79 / 41.69$ & $10.36 / 3.26$ & $0.0012 / \mathrm{ns}$ \\
\hline & & $\mathrm{R} \times \mathrm{T}$ & 12 & $343.66 / 153.25$ & 28.64/12.77 & & \\
\hline & & Treatment (Trt) & 3 & $21895.68 / 3209.44$ & $7298.56 / 1069.81$ & $176.13 / 49.88$ & $0.0001 / 0.0001$ \\
\hline & & $\mathrm{T} \times \mathrm{Trt}$ & 9 & $452.19 / 79.22$ & $50.24 / 8.80$ & $1.21 / 0.41$ & $\mathrm{~ns} / \mathrm{ns}$ \\
\hline \multirow[t]{5}{*}{1999} & Leaf & Replication (R) & 2 & $11.21 /---$ & $5.60 /---$ & & \\
\hline & & Timing $(\mathrm{T})^{\mathrm{z}}$ & 3 & 7.11/--- & 2.37/--- & 1.53/--- & ns/--- \\
\hline & & $\mathrm{R} \times \mathrm{T}$ & 6 & 9.31/--- & 1.55/--- & & \\
\hline & & Treatment (Trt) & 3 & 338.39/--- & 112.80/--- & 43.97/--- & 0.0001/--- \\
\hline & & T×Trt & 9 & 21.34/--- & 2.37/--- & 0.92/--- & ns/--- \\
\hline
\end{tabular}

${ }^{\mathrm{x}}$ Statistical values presented are based on leaf or fruit samples (leaf/fruit). Dashed lines $(---)=$ no disease data.

${ }^{\mathrm{y}}$ Levels of significance: highly significant $(P<0.01)$, significant $(P<0.10)$, and ns $=$ not significant $(P>0.10)$.

${ }^{\mathrm{z}}$ Test of hypothesis using ANOVA mean square (MS) for $\mathrm{R} \times \mathrm{T}$ as an error term.

Table 7. Efficacy of treatments and application timings on reducing rust incidence on leaves and fruit of cling peach cv. Andross in the spring of 1998 and 1999 in Live Oak, CA

\begin{tabular}{|c|c|c|c|c|c|c|c|c|c|c|c|c|}
\hline \multirow[b]{3}{*}{ Treatment $^{\mathrm{z}}$} & \multicolumn{12}{|c|}{ Disease incidence $(\%)^{\mathrm{y}}$} \\
\hline & \multicolumn{3}{|c|}{ ASLD } & \multicolumn{3}{|c|}{ AFR } & \multicolumn{3}{|c|}{ ASLD/AFR } & \multicolumn{3}{|c|}{ AFR/ASR } \\
\hline & $\begin{array}{l}\text { Leaf } \\
1998\end{array}$ & $\begin{array}{l}\text { Fruit } \\
1998\end{array}$ & $\begin{array}{l}\text { Leaf } \\
1999\end{array}$ & $\begin{array}{l}\text { Leaf } \\
1998\end{array}$ & $\begin{array}{c}\text { Fruit } \\
1998\end{array}$ & $\begin{array}{l}\text { Leaf } \\
1999\end{array}$ & $\begin{array}{l}\text { Leaf } \\
1998\end{array}$ & $\begin{array}{c}\text { Fruit } \\
1998\end{array}$ & $\begin{array}{l}\text { Leaf } \\
1999\end{array}$ & $\begin{array}{l}\text { Leaf } \\
1998\end{array}$ & $\begin{array}{c}\text { Fruit } \\
1998\end{array}$ & $\begin{array}{l}\text { Leaf } \\
1999 \\
\end{array}$ \\
\hline Control & $48.2 \mathrm{a}$ & $7.3 \mathrm{a}$ & $0.7 \mathrm{a}$ & $52.0 \mathrm{a}$ & $11.0 \mathrm{a}$ & $2.0 \mathrm{a}$ & $45.1 \mathrm{a}$ & $8.8 \mathrm{a}$ & $1.7 \mathrm{a}$ & $53.7 \mathrm{a}$ & $9.3 \mathrm{a}$ & --- \\
\hline Azoxystrobin & $0.4 \mathrm{c}$ & $0.0 \mathrm{c}$ & $0.0 \mathrm{~b}$ & $6.8 \mathrm{~b}$ & $0.7 \mathrm{~b}$ & $0.0 \mathrm{~b}$ & $0.4 \mathrm{~b}$ & $0.0 \mathrm{~b}$ & $0.0 \mathrm{~b}$ & $7.4 \mathrm{~b}$ & $0.5 \mathrm{~b}$ & --- \\
\hline Tebuconazole & $0.0 \mathrm{c}$ & $0.3 \mathrm{c}$ & $0.0 \mathrm{~b}$ & $0.4 \mathrm{c}$ & $0.2 \mathrm{~b}$ & $0.0 \mathrm{~b}$ & $0.0 \mathrm{~b}$ & $0.0 \mathrm{~b}$ & $0.0 \mathrm{~b}$ & $0.4 \mathrm{c}$ & $0.2 \mathrm{~b}$ & --- \\
\hline Wettable sulfur & $9.0 \mathrm{~b}$ & $3.0 \mathrm{~b}$ & $0.0 \mathrm{~b}$ & $13.1 \mathrm{~b}$ & $4.3 \mathrm{ab}$ & $0.0 \mathrm{~b}$ & $2.6 \mathrm{~b}$ & $1.3 \mathrm{~b}$ & $0.0 \mathrm{~b}$ & $10.8 \mathrm{~b}$ & $4.8 \mathrm{a}$ & --- \\
\hline Spray timing_Leaf-1998 & $14.4 \mathrm{~B}$ & & & $18.0 \mathrm{~A}$ & & & $12.0 \mathrm{~B}$ & & & $18.1 \mathrm{~A}$ & & \\
\hline Spray timing_Fruit-1998 & & $2.7 \mathrm{~A}$ & & & $4.0 \mathrm{~A}$ & & & $2.5 \mathrm{~A}$ & & & $3.7 \mathrm{~A}$ & \\
\hline Spray timing-Leaf-1999 & & & $0.2 \mathrm{~A}$ & & & $0.5 \mathrm{~A}$ & & & $0.4 \mathrm{~A}$ & & & --- \\
\hline
\end{tabular}

${ }^{y}$ Disease incidence was based on 210 leaves and 120 fruit for each of four single-tree replications per treatment. Means followed by the same letter are not significantly different according to Duncan's multiple range test $(P>0.05)$. Treatment comparisons are by column, whereas comparisons of timing of applications are by row.

${ }^{\mathrm{z}}$ Treatments were applied after stem lesion detection (ASLD), after the first rain (AFR), and after the second rain (ASR). Dates of application were 15 April (ASLD), 9 May (AFR), and 1 June (ASR) in 1998 and on 30 April (ASLD) and 4 June (AFR) in 1999. 
tions to rain events with temperatures $\geq 15^{\circ} \mathrm{C}$, but this needs to be validated. Thus, the ASLD application likely provided less protection than the other applications against fungal infection during the rain events in May. For protection against fruit infections on cv. Ross in 1996, similar trends were observed as on leaves. In 1997, programs that included the ASLD application (e.g., ASLD and ASLD and before-the-firstforecasted-rain timings) were generally more effective (Tables 3 and 5), probably because temperatures were higher following ASLD and thus more conducive for fungal infection during precipitation events.

In greenhouse studies with azoxystrobin and tebuconazole, we demonstrated the postinfection activity of these fungicides (Fig. 2). Previously, Kable et al. (12) showed that SBI fungicides such as propiconazole and myclobutanil (i.e., RH-3866) have curative activity with up to 7-dayspostinoculation suppression of prune leaf rust. Other SBI fungicides have been used for curative action for apple scab (21) and apple rust (19). SBI fungicides and azoxystrobin have also been used as postinfection treatments for citrus scab (4). Thus, in our 1998 and 1999 field trials, selected treatments representing contact (e.g., wettable sulfur) and postinfection activity (e.g., tebuconazole and azoxystrobin) fungicides were utilized in different application strategies from the protective programs that are described above. Treatments were applied after stem lesion detection or after actual rain events, provided that a two-week interval had occurred after the previous fungicide application. This approach allowed for more efficient use of fungicide applications. Thus, in 1998 and 1999, a maximum of three or two applications was done as shown in Figure $3 \mathrm{G}$ and $\mathrm{H}$, respectively. In 1998, the highest precipitation and, subsequently, the highest disease incidence on leaves and fruit were observed. In 1999, however, the lowest precipitation and disease incidence were observed among all years when trials were conducted. In 1998, fungicides applied ASLD or ASLD and after the first rain were significantly more effective than applications made after the first rain or after the first and second rains (Table 7). Thus, utilization of protective (ASLD) and protective and postinfection (ASLD and after the first rain) strategies was highly effective for managing the disease during an unusually wet spring season. Furthermore, in a much drier spring season such as 1999, one application after stem lesion detection had statistically the same efficacy as the one- or two-applications after the first and second rains.

This is the first time that inoculum and precipitation have been effectively used experimentally and commercially for managing peach rust. Previous strategies for rust on stone fruit in California followed calendar-based applications with two to four treatments of fungicides $(8,9,11,14,20)$. A forecasting model based only on environmental monitoring has been developed for stone fruit rust on prune in New South Wales (13). In this model, urediniospore inoculum on leaves was presumed to be present in orchards every year, although the disease caused moderate to severe epidemics with a 1-in-4-year probability. In our studies, we observed that sporulating stem lesions in the spring and early spring rains initiate early-season leaf and fruit epidemics of economic importance (23). The current strategy for managing the disease on peach in California is therefore as follows: an application of any registered class of fungicide (e.g., elemental sulfur, SBI, or strobilurin) at ASLD, followed by spring season applications of a different class of fungicide (but not a sulfur compound due to lack of curative action) after a rain event that occurs at least two weeks after the previous fungicide application. This program has reduced the number of fungicide applications to two in years with high rainfall and to one application in years when stem lesions are present but no subsequent rains occur. If stem lesions are not detected, it is possible that no fungicide applications may be required. This situation arose in the spring of 2000 and 2001 and no fungicides were applied in selected commercial orchards. With low spring rainfall and no inoculum present, rust was not detected in the summer seasons of these two years (J. E. Adaskaveg, unpublished data). Thus, our model will continue to be evaluated on a commercial basis.

\section{ACKNOWLEDGMENTS}

We thank the California Cling Peach Board for financially supporting this research, as well as John and George Post of AgAdvisors, Dave Thompson, Bill Manji, and grower cooperators in the Sacramento Valley for their assistance during field experiments.

\section{LITERATURE CITED}

1. Adaskaveg, J. E., Soto-Estrada, A., Förster, H., Thompson, D., Hasey, J., Manji, B. T., and Teviotdale, B. 2000. Peach rust caused by Tranzschelia discolor in California. Univ. Calif. Div. Agric. Nat. Res., Oakland, CA. Public. No. 8011.

2. Barrett, J. T. 1915. Observations on prune rust, Puccinia pruni-spinosae Pers. in southern California. (Abstr.) Phytopathology 5:293.

3. Bertrand, P. F. 1995. Rust. Pages 23-24 in: Compendium of Stone Fruit Diseases. J. M. Ogawa, E. I. Zehr, G. W. Bird, D. F. Ritchie, K. Uriu, and J. K. Uyemoto, eds. American Phytopathological Society, St. Paul. MN.

4. Bushong, P. M., and Timmer, L. W. 2000. Evaluation of postinfection control of citrus scab and melanose with benomyl, fenbuconazole, and azoxystrobin. Plant Dis. 84:1246-1249.

5. Doepel, R. F., and Hardisty, S. E. 1963. Rust of stone fruit. Results of some recent spray trials. J. Agric. West. Aust. 4:525-531.

6. Duan, C. H., Tsai, W. H., and Tu, C. C. 1992. An efficient laboratory test for screening fungicides against Tranzschelia discolor from peach. Plant Prot. Bull. 34:70-73.

7. Duruz, W. P. 1928. Further notes regarding peach rust control. Proc. Am. Soc. Hortic. Sci. 25:333-337.
8. Duruz, W. P., and Goldsworthy, M. C. 1928 Spraying for peach rust (a progress report). Am. Soc. Hortic. Sci. 24:168-171.

9. Goldsworthy, M. C., and Smith, R. E. 1931. Studies on rust of cling peaches in California. Phytopathology 21:133-168.

10. Grove, G., and Boal, R. J. 2000. Managing powdery mildew of cherry in Washington orchards and nurseries with spray oils. Plant Health Progress 28 July 2000 . On-line publication.

11. Kable, P. F., Bambach, R. W., Ellison, P. J., Watson, A., and Kaldor, C. J. 1987. Fungicidal control of rust of French prune caused by Tranzschelia discolor. Aust. J. Agric. Res. 38:565-576.

12. Kable, P. F., Keen, J. B., and Bambach, R. W. 1987. Evaluation of fungicides for curative activity against Tranzschelia discolor, cause of the rust disease of French prune (Prunus domestica L.). Aust. J. Agric. Res. 38:577-585.

13. Kable, P. F., Milligan, M. J., Wilson, P., Slack, J. M., Ellison, P. J., Watson, A., and Hannah, R. S. 1991. A computer-based system for the management of the rust disease of French prunes. Bull. OEPP/EPPO Bull. 21:573-580.

14. Michailides, T. J., and Ogawa, J. M. 1986. Chemical control of prune leaf rust (Tranzschelia discolor f. sp. domesticae) in California. Plant Dis. 70:307-309.

15. Ogawa, J. M., and English, H. 1991. Disease of temperate zone tree fruit and nut crops. Univ. Calif. Div. Agric. Nat. Res., Oakland, CA. Public. No. 3345.

16. Ogawa, J. M., Manji, B. T., Adaskaveg, J. E., and Michailides, T. J. 1988. Population dynamics of benzimidazoles-resistant Monilinia species on stone fruit trees in California. Pages 36-39 in: Fungicide Resistance in North America. C. J. Delp. ed. American Phytopathological Society, St. Paul, MN.

17. Orpin, C., Bauer, A., Bieri, R., Faugeron, J. M., and Siddi, G. 1986. Myclobutanil, a broad-spectrum systemic fungicide for use on fruit, vines and a wide range of other crops. Pages 55-62 in: British Crop Protection Conference-Pests Disease. BCPC Publications, Croydon, England.

18. Pierce, N. B. 1894. Prune rust. J. Mycol. 7:354-363.

19. Pearson, R. C., Szkolnik, M., and Meyer, F. W. 1978. Suppression of cedar apple rust pycnia on apple leaves following postinfection application of fenarimol and triforine. Phytopathology 68:1805-1809.

20. Reuveni, M. 2000. Efficacy of trifloxystrobin (Flint), a new strobilurin fungicide, in controlling powdery mildews on apple, mango and nectarine, and rust on prune trees. Crop Prot.19:335-341.

21. Schwabe, W. F. S., Jones, A. L., and Jonker, J. P. 1984. Greenhouse evaluation of the curative and protective action of sterol-inhibiting fungicides against apple scab. Phytopathology 74:249-252.

22. Soto-Estrada, A., and Adaskaveg, J. E. Managing peach rust in California using new fungicides and inoculum-precipitation based application strategy. (Abstr., Pacific Division) Phytopathology. In press.

23. Soto-Estrada, A., Adaskaveg, J. E., Manji, B. T., Hasey, J. 1998. Early and late season rust epidemics on cling peach and their effect on crop production in California. (Abstr.) Phytopathology 88:S84.

24. Soto-Estrada, A., Eddleman, C. D., and Adaskaveg, J. E. 2000. Development and symptom expression of rust caused by Tranzschelia discolor in shoots and leaves of cling peach. (Abstr.) Phytopathology 90:S121.

25. Wilson, E. E., and Scott, C. E. 1943. Prevention of three peach diseases by ferric dimethyldithiocarbamate spray. Phytopathology 33:962-963. 